\title{
Baccharis trimera aqueous extract modulates inflammation and nociception in mice
}

Natiely Silveira de Almeida', Alexandre de Barros Falcão Ferraz ${ }^{1,2}$, Claudia Pedron², Dione Silva Correa ${ }^{1}$, Luciene Bruno Vieira ${ }^{3}$, Flavia Tasmim Techera Antunes ${ }^{2}$ and Alessandra Hubner de Souza ${ }^{1,2^{*}}$ (D)

\begin{abstract}
Background: The aerial parts of Baccharis trimera (Less.) are frequently used as a tea to treat several diseases. Therefore, the aim of this study was to identify the constituents of an aqueous extract of $B$. trimera, focusing on their antioxidant, anti-inflammation, and antinociception activities and properties. For that, the researchers performed in vivo assays using the formalin test and Freund's Complete Adjuvant (FCA) to measure the acute and chronic inflammatory pain in mice. Moreover, the myeloperoxidase enzyme (MPO) was analyzed in the subcutaneous tissue after the FCA injection, together with the counting of lymphocytes in the peripheral blood of the mice.
\end{abstract}

Results: The qualitative phytochemical analysis indicated the presence of flavonoids and saponins in the $B$. trimera aqueous extract. The high-performance liquid chromatography (HPLC) analyses showed the presence of phenolic compounds, such as chlorogenic acid, ellagic acid, rosmarinic acid, as well as flavonoids, such as rutin, quercetin, and luteolin. The DPPH assay was used in order to measure the antioxidant activity of the aqueous extract of $B$. trimera and this showed an $I_{50}$ of $118.18 \pm 1.02 \mu \mathrm{g} / \mathrm{mg}$. The data from the formalin test demonstrated that a single dose of the aqueous extract of $B$. trimera was not able to decrease the nociceptive behavior during the neurogenic phase, at any of the tested doses (20,40, or $80 \mathrm{mg} / \mathrm{kg}$ p.o.). However, during the inflammatory phase of this test, the aqueous extract of $B$. trimera at $80 \mathrm{mg} / \mathrm{kg}$ (p.o.) significantly decreased the nociceptive behavior, showing more effectiveness when compared to the other tested doses $(p<0.05)$. Importantly, in the chronic inflammatory model on the 5th day of treatment, the aqueous extract of $B$. trimera $(80 \mathrm{mg} / \mathrm{kg}$ p.o.) significantly reduced mechanical allodynia $(p<0.01)$, heat thermal hyperalgesia $(p<0.001)$, and paw edema $(p<0.05)$. There were no changes in the MPO activity, but the data exhibited an equivalent decrease in the number of lymphocytes in the blood of the mice that were treated with $B$. trimera (80 mg. $\mathrm{kg}^{-1}$ p.o.) and diclofenac sodium.

Conclusion: Taken together, the present data reinforces the potential of the $B$. trimera aqueous extract as an antiinflammatory and analgesic compound.

Keywords: Anti-inflammatory effect, Antioxidant assay, Flavonoids, Phenolic compounds, Von Frey test, Hot plate test

\footnotetext{
* Correspondence: alessandrahubnersouza@gmail.com

'Graduate Program in Genetics and Toxicology (PPGGTA), Lutheran

University of Brazil, Av. Farroupilha, no 8001, Bairro São José, Canoas, RS

92425-900, Brazil

${ }^{2}$ Graduate Program in Cellular and Molecular Biology Applied to Health,

Lutheran University of Brazil, Canoas, RS 92425-900, Brazil

Full list of author information is available at the end of the article
}

\section{Springer Open}

(c) The Author(s). 2021 Open Access This article is licensed under a Creative Commons Attribution 4.0 International License, which permits use, sharing, adaptation, distribution and reproduction in any medium or format, as long as you give appropriate credit to the original author(s) and the source, provide a link to the Creative Commons licence, and indicate if changes were made. The images or other third party material in this article are included in the article's Creative Commons licence, unless indicated otherwise in a credit line to the material. If material is not included in the article's Creative Commons licence and your intended use is not permitted by statutory regulation or exceeds the permitted use, you will need to obtain permission directly from the copyright holder. To view a copy of this licence, visit http://creativecommons.org/licenses/by/4.0/. 


\section{Background}

The inflammatory process ensures cellular and tissue survival in those cases of an acute tissue lesion or infection. However, in chronic cases, the suppression of inflammation is necessary, in order to reduce the pain and to preserve the integrity of the tissue [1]. Chemical mediators are responsible for tissue inflammation, acting on the nociceptive nerve endings to lower the neuronal excitation threshold, and to sensitize the afferent firing rate, leading to the development of allodynia and hyperalgesia, respectively [2]. The medicinal practice of using plants, their parts, or extracts for therapeutic purposes has been acknowledged since antiquity [3]. In this scenario, natural plant products have been studied as an important perspective of developing therapeutic agents. Moreover, there is an urgent need to develop herbal medicines, which have scientific proof of efficacy, safety, and quality [4].

The Baccharis trimera (Less.) plant is originally from South Brazil, Paraguay, Uruguay, and Argentina. It is an official species listed in the Brazilian Pharmacopoeia [5]. B. trimera is a perennial subshrub popularly known as "carqueja" that belongs to the Asteraceae family, and its aerial parts are used as a tea, in order to treat several disorders $[6,7]$. According to phytochemical studies, flavonoids, terpenes, phenolic acids, and chlorogenic acids are the main classes of compounds that are identified in the aerial parts of $B$. trimera [8]. The literature has reported biological activities from this species as an antioxidant, anti-inflammation, liver and gastric protector, antimicrobial, antifungal, and antiparasitic [8, 9]. Furthermore, the polyphenols from $B$. trimera have shown great potential for anti-inflammatory properties that are associated with antioxidant activity, plus inhibitory enzymatic actions that are involved in the production of eicosanoids [10, 11].

Paul et al. (2009) showed anti-inflammatory effects of aqueous extracts of $B$. trimera (400 and $800 \mathrm{mg} / \mathrm{kg}$ i.p.) in an inflammatory model of carrageenan-induced pleurisy in rats [12]. Moreover, the butanolic fraction [13], the phenolic enriched extract [14], and the ethanolic supernatant fraction [15], all from crude aqueous extracts of this species, also displayed anti-inflammatory effects, which were comparable to low doses of indomethacin. Furthermore, the pretreatment with the B. trimera extract was able to significantly decrease the production of reactive oxygen species (ROS) in the neutrophils of Fisher rats [16]. In addition, Rodrigues et al. (2009) showed antigenotoxic effects in the blood of the mice that were treated with $B$. trimera and this was able to prevent cellular damage that was induced by hydrogen peroxide [17].

As stated, the suppression of inflammation and ROS was necessary to reduce the pain. Thus, the compounds that were previously identified in the aerial parts of $B$. trimera showed anti-inflammatory and antioxidant activities. Nevertheless, the anti-inflammatory and antinociceptive activities of the aqueous extracts from the aerial parts of B. trimera need to be further explored. Thus, this article aimed to evaluate those activities by administrating orally in mice, aqueous extracts of $B$. trimera in acute and chronic inflammatory models of nociception. The study also investigated the effects of this treatment on the white blood cell count and on the myeloperoxidase activity in the peripheral tissue that was affected by the chronic inflammation.

\section{Material and methods}

The qualitative phytochemical analysis of the B. trimera aqueous extract was performed to evaluate the presence of chemical compounds. The antioxidant capacity was also evaluated. After that, the anti-inflammatory effect of the aqueous extract was evaluated in vivo in the acute inflammatory pain model (Formalin test), in order to proceed to the next evaluation of the chronic inflammatory model (CFA into the paw).

\section{Collection of the plant material}

The aerial parts of B. trimera were collected in July 2013 in the city of Bagé, Rio Grande do Sul, Brazil. The samples collected were identified and a specimen voucher (Naresuan University of the Campanha Region, under number 00014) was deposited at the Nicanor Risch Herbarium in the University of the Campanha Region (URCAMP). The access to Brazilian biodiversity was registered in the National System for Management of the Genetic Heritage and the Associated Traditional Knowledge (SISGEN), under protocol A02A526.

\section{Sample preparation}

The aerial parts were dried at room temperature and protected against the sunlight for 7 days. Afterward, the dried plant $(250 \mathrm{~g})$ was finely ground and the aqueous extracts were prepared by infusion at $80^{\circ} \mathrm{C}(1 / 10$ plant/ water solvent). The infusion was kept at room temperature for $30 \mathrm{~min}$. After cooling and filtration, the extract was frozen and then concentrated by lyophilization for 5 days overnight, in order to obtain the aqueous extract of B. trimera (29.25 g, yield: $11.7 \%$, w/w). This extract was kept in a vacuum desiccator to avoid changes in its chemical profile.

\section{Chemicals}

The solvents that were used for the HLPC analyses, together with the other necessary chemicals, were purchased from Merck (Darmstadt, Germany). These were Quercetin (QE) (Sigma, St. Louis, MO, USA); Gallic Acid (GA) (Sigma, St. Louis, MO, USA); 3-(2,3- 
dihydroxyphenyl) propionate (DPPH) (Sigma, St. Louis, MO, USA); Freund's Complete Adjuvant (FCA) (Sigma Chemical Co., St. Louis, MO, USA); Formaldehyde (Vetec, Rio de Janeiro, Brazil); and Diclofenac Sodium (Medley, São Paulo, Brazil).

\section{Phytochemical screening}

The crude B. trimera aqueous extract was submitted to qualitative phytochemical screening, as described by Harborne (1998) [18]. The method consists of colorimetric reactions for the qualitative detection of flavonoids, tannins, anthraquinones, alkaloids, saponins, coumarins, and cardiac glycosides. The thin-layer chromatography analyses were performed according to Wagner and Bladt (1996) [19].

\section{High-performance liquid chromatography (HPLC) analyses} The HPLC analyses were performed on a Waters Alliance 2695 Separation Module (Milford, Massachusetts, USA), with a double wavelength UV detector (Waters 2487 ) that was controlled by an interface module (IEEE$488)$. For the stationary phase, a reverse phase $(250 \times 4.6$ $\mathrm{mm}-5$ one particle diameter Waters Spherisorb ODS2 HPLC Column was used. Reference standards were used as the external standards. A constant flow of $1 \mathrm{~mL} \cdot \mathrm{min}^{-1}$ was used during the analyses. HPLC-grade solvents and Milli- $Q^{\circ}$ water were used in the chromatographic studies. The mobile phase was prepared daily and degassed by sonication before use. The phenolic acids and flavonoids were quantitatively determined at $254 \mathrm{~nm}$ when using pure acetonitrile (A) and $0.1 \%$ phosphoric acid (H3PO4) (B) as the mobile phase. The gradient system was adjusted to $0 / 95,20 / 86,70 / 65$ ( $\mathrm{min} / \% \mathrm{~B}$ ). The correlation of the chromatographic peaks was obtained by comparing the experimental retention times with the reference standards and by the co-injection of the sample and the authentic samples. The standard solutions were prepared in different concentrations. The quantitative analyses of the phenolic compounds were performed by constructing five-point calibration curves for each standard solution, which showed the linearity of the detector response in the range of $8.0 \mu \mathrm{g} \cdot \mathrm{min}^{-1}$ to $225 \mu \mathrm{g} \cdot \mathrm{min}^{-1}$. The correlation coefficient value was greater than 0.9985 .

The LOD detection $\left(\leq 0.64 \mu \mathrm{g} \cdot \mathrm{min}^{-1}\right)$ and the quantification limits $\left(\mathrm{LOQ} \leq 2.15 \mu \mathrm{g} \cdot \mathrm{min}^{-1}\right)$ were calculated by using the parameters of the calibration curves, being defined as 3.3 and 10 times the value of the regression error, divided by the slope, respectively. The LOD and LOQ values were always lower than the lowest tested standard concentration in the dynamic range of the calibration curves, indicating a satisfactory sensitivity for each phenolic standard. All of the chromatographic operations were performed in triplicate at room temperature [20].

\section{Total phenolic compound content}

The content of the total phenolic compounds in B. trimera was determined by the Folin-Ciocalteu method. For the calibration curves, aliquots of $1 \mathrm{~mL}$ of gallic ethanolic acid solutions at concentrations of 0.015 , 0.024, 0.075, and $0.105 \mathrm{mg} \cdot \mathrm{min}^{-1}$ were mixed with $5 \mathrm{~mL}$ of Folin-Ciocalteu reagent (diluted ten times) and $4 \mathrm{~mL}$ (75 g.L $\mathrm{L}^{-1}$ ) of sodium carbonate. The absorption was detected after $30 \mathrm{~min}$ at $765 \mathrm{~nm}$ and the calibration curve was drawn [21]. One (1) $\mathrm{mL}$ of a solution of B. trimera $\left(0.1 \mathrm{mg} \cdot \mathrm{mL}^{-1}\right)$ was mixed with the same reagents as described above, and after $1 \mathrm{~h}$, the absorption was measured to determine the total amount of the phenols. All of the determinations were performed in triplicate. The total phenol content was expressed as a gallic acid (GAE) equivalent in $\mathrm{mg} \cdot \mathrm{g}^{-1}$ of extract.

\section{Total flavonoid content}

The total flavonoid content of the samples was determined by a colorimetric method, as previously described using aluminum chloride [22]. Solutions containing different concentrations of quercetin were prepared to establish a calibration curve $\left(2-12 \mu \mathrm{g} \cdot \mathrm{mL}^{-1}\right)$. After 30 min, the absorption at $425 \mathrm{~nm}$ was measured for each solution in a Shimadzu Spectrophotometer (UV-1602PC, Kyoto, Japan). The analyses were performed in triplicate, and the total flavonoid content in the samples was expressed as quercetin equivalents (QE) in $\mathrm{mg} \cdot \mathrm{g}^{-1}$ extract.

\section{Antioxidant DPPH assay}

The ability of the crude aqueous extract of $B$. trimera to extinguish stable DPPH (2,2-Diphenyl-1-picrylhydrazyl) was measured according to Mensor et al., (2001) [23]. Ten milligrams of $B$. trimera extract were weighed and diluted in methanol to obtain six distinct concentrations (50, 100. 150, 200, 250, and $300 \mu \mathrm{g} / \mathrm{mL}$ ). Afterward, 2.5 $\mathrm{mL}$ of the sample was transferred to a $3.5 \mathrm{~mL}$ cuvette and $1 \mathrm{~mL}$ of the DPPH solution $(0.2 \mathrm{mg} / \mathrm{mL})$ was added. Methanol (blank), DPPH/methanol (positive control), and quercetin (standard) were used to evaluate the antioxidant activity. After $30 \mathrm{~min}$, the absorbance was measured at $518 \mathrm{~nm}$ when using a Shimadzu Spectrophotometer (UV$1602 \mathrm{PC}$, Kyoto, Japan). The measurements were performed in triplicate, and the antioxidant activity was calculated according to the formula:

$\% \mathrm{DPPH}$ inhibition $=[($ Abscontrol $(+)$-Absample $) \times 100] /$ Abscontrol $(+)$

\section{Animals}

105 Swiss male mice (35-40 g) were obtained from the Vivarium of the Lutheran University of Brazil (ULBRA). The animal care and experimental procedures were 
strictly conducted in accordance with the ARRIVE Guidelines [24]. All of the experiments were performed under the Consent and Surveillance of the Ethics Committee for Using Animals from ULBRA under Protocol $\mathrm{n}^{\circ}$ 2013-20P. Five mice per box were maintained with food and water ad libitum in a temperature-controlled room $\left(24 \pm 2{ }^{\circ} \mathrm{C}\right)$, while under a 12 -h light/dark cycle.

\section{Treatments}

In order to analyze the anti-inflammatory and antinociceptive effects of the aqueous extract of $B$. trimera, the mice were treated with doses of 20,40 , and $80 \mathrm{mg} \cdot \mathrm{kg}^{-1}$ aqueous extract, diclofenac sodium $\left(5 \mathrm{mg} \cdot \mathrm{kg}^{-1}\right.$, a nonsteroidal anti-inflammatory drug used to treat pain and inflammatory diseases), and water $\left(10 \mathrm{mg} \cdot \mathrm{kg}^{-1}\right)$ by the gavage route (p.o.).

\section{Formalin test}

The formalin test was performed according to Hunskaar and Hole (1987) [25]. To evaluate whether the B. trimera extract (20, 40, and $80 \mathrm{mg} \cdot \mathrm{kg}^{-1}$ ) prevented the presence of nociception, the mice received a pretreatment with the compound orally, one hour before the intraplantar administration of $1.5 \%$ formalin, in the right hind leg $(20 \mu \mathrm{L}$ s.c.). The licking of the paw time, or its removal from the floor, was recorded as an indication of nociception. The animals were observed for 30 min, divided into two phases. The first phase was evaluated at $0-5$ min after the formalin injection (neurogenic phase), and the second phase was evaluated at 15-30 min (inflammatory phase).

\section{Chronic inflammatory model induced by Freund's complete adjuvant (FCA)}

The chronic inflammation model was induced by then intraplantar injection of FCA $(20 \mu \mathrm{L})$ into the right-hind paw of the mice [26]. To investigate the actions of the extract of $B$. trimera, the mice received a daily dose of $80 \mathrm{mg} . \mathrm{kg}^{-1}$, p.o., for five consecutive days, starting from the first day of the FCA injection. The effect of edema on the paw that was produced by FCA was evaluated 48 $h$ later, and then again on the last day of treatment. Paw edema was expressed by comparing the paw thickness $(\mathrm{mm})$ to the baseline measurement.

\section{Thermal hyperalgesia}

The exposure of the peripheral sensory nerve endings to elevated temperatures can evoke sensations of warmth, heat, or pain [27]. After the chronic inflammation induction by the intraplantar injection of FCA $(20 \mu \mathrm{L})$ into the right-hind paw of the mice, one hour after the treatment (water, extract, diclofenac), the mice were placed on a hot metal plate $\left(52 \pm 0.5^{\circ} \mathrm{C}\right)$ and the behavior was evaluated. The time of each animal when they licked or elevated their paw was recorded. A cut-off time of 30 $\mathrm{s}$ was established to avoid pain or damage to the animal [28].

\section{Mechanical allodynia}

Mechanical allodynia was evaluated when using Von Frey's filaments $(0.02-10 \mathrm{~g})$, as described by Dixon (1980) [29], at three different moments. Firstly, one hour before the injection of FCA into the mice paw. Secondly, $48 \mathrm{~h}$ after the first application. Thirdly, on the last day of the treatments.

The animals were acclimatized for $1 \mathrm{~h}$ in individual acrylic compartments with a mesh floor. Von Frey filaments were perpendicularly directed to the right-hind paw plantar surface of the animals, with enough high pressure to bend the filament. Starting with an application of the $0.4 \mathrm{~g}$ filament, if the tension-response was harmful (paw withdrawal), a filament with less value was used. However, if the response was innocuous, the next filament with a higher force was tested. At least six responses around the estimated threshold were required for the optimal calculation of the 50\% withdrawal threshold (PWT).

\section{Myeloperoxidase measurement (MPO)}

To investigate the involvement of neutrophils in the inflammatory response that was induced by FCA, the researchers measured the MPO activity. After the last behavioral test, the mice were euthanized by an isoflurane overdose, followed by cervical dislocation. The plantar surface of the rear paw was collected to determine the activity of the MPO as described by Suzuki et al., 1983 [30]. The values were expressed as optical densities, corrected by a gram of homogenized tissue $(\mathrm{OD} / \mathrm{g}$ tissue).

\section{White blood cell count}

The white blood cell count test was performed as described by Bentley et al., 1980 [31]. Briefly, $50 \mu \mathrm{L}$ of peripheral blood was placed on the slide and with the help of a distending slide, the smear was performed. After drying, the slides were stained with methylene blue eosinate, while going through three processes: fixation, staining, and washing. After drying again, these slides were visualized and analyzed under a microscope at $10 \mathrm{x}$ and $40 \times$ magnification. A differential count of the blood cells was then performed, with an emphasis on the segmented cells that were present with coverage in the inflammatory process.

\section{Statistical analysis}

The data is expressed as mean \pm SEM. The statistical analyses were carried out by One-Way or Two-Way Analysis of Variance (ANOVA), followed by the 
Student-Newman-Keuls (SNK) test, or the Bonferroni test (GraphPad Prism 5.0, USA). In all of the comparisons, values of $p<0.05$ were considered statistically significant.

\section{Results}

Phytochemical analysis of the $B$. trimera aqueous extract The data indicated the presence of flavonoids and saponins in the $B$. trimera aqueous extract. Furthermore, the researchers observed a content of $120.79 \pm 10.45 \mathrm{mg} . \mathrm{g}^{-1}$ GAE in the total of phenolic compounds, and $6.98 \pm$ $0.06 \mathrm{mg} \cdot \mathrm{g}^{-1} \mathrm{QE}$ in the total of flavonoids. The HPLC analyses (Fig. 1) showed the presence of three phenolic acids, chlorogenic acid $\left(32.21 \pm 0.17 \mathrm{mg} . \mathrm{g}^{-1} ; \mathrm{t}_{\mathrm{R}} 14.6\right.$ $\mathrm{min})$, ellagic acid $\left(23.19 \pm 0.21 \mathrm{mg} . \mathrm{g}^{-1} ; \mathrm{t}_{\mathrm{R}} 34.6 \mathrm{~min}\right)$, and rosmarinic acid $\left(40.34 \pm 0.19 \mathrm{mg} \cdot \mathrm{g}^{-1} ; \mathrm{t}_{\mathrm{R}} 37.9 \mathrm{~min}\right)$, as well as three flavonoids, rutin $\left(37.51 \pm 0.26 \mathrm{mg} \cdot \mathrm{g}^{-1} ; t_{R}\right.$ $32.8 \mathrm{~min}$ ), luteolin $\left(3.98 \pm 0.06 \mathrm{mg} \cdot \mathrm{g}^{-1} ; \mathrm{t}_{\mathrm{R}} 49.3 \mathrm{~min}\right)$, and quercetin $\left(1.34 \pm 0.08 \mathrm{mg} . \mathrm{g}^{-1} ; \mathrm{t}_{\mathrm{R}} 48.0 \mathrm{~min}\right)$.

\section{Antioxidant activity of the aqueous extract of $B$. trimera} The antioxidant activity of the aqueous extract of $B$. trimera was measured by three single experiments using six concentrations (50,100, 150, 200, 250, and $300 \mu \mathrm{g} / \mathrm{ml})$. After each experiment, the $\mathrm{IC}_{50}$ was calculated (Experiment 1: $\mathrm{IC}_{50}=117.49 \mu \mathrm{g} / \mathrm{ml} ;$ Experiment 2: $\mathrm{IC}_{50}=116.86 \mu \mathrm{g} / \mathrm{ml}$; Experiment 3: $\left.\mathrm{IC}_{50}=120.19 \mu \mathrm{g} / \mathrm{ml}\right)$. The value of $\mathrm{IC}_{50}$ of the aqueous extract of $B$. trimera was $118.18 \pm 1.02 \mu \mathrm{g} / \mathrm{mL}$.

\section{Treatment of $B$. trimera reduces nociceptive behavior}

The formalin assay was performed to evaluate the nociceptive behavior in the treated mice. This involved moderate or continuous pain, which is generated by the injured tissue [32]. During the neurogenic phase, none of the mice that were treated with the different doses of the aqueous extract of $B$. trimera (20 mg. $\mathrm{kg}^{-1}: 231.6 \pm$ $10.14 \mathrm{~s} ; 40$ mg. $\mathrm{kg}^{-1}: 232.3 \pm 11.35$ s; $80 \mathrm{mg} \cdot \mathrm{kg}^{-1}: 204.9 \pm$ 13.70s) presented statistical differences in the nociceptive responses when compared to the control group $(233.8 \pm 11.99)$. Neither did the diclofenac group $(174.6 \pm 17.74 \mathrm{~s}, p<0.05)$ when compared to the control group (Fig. 2A). However, during the inflammatory phase, the dose of $80 \mathrm{mg} . \mathrm{kg}^{-1}(254.2 \pm 39.77 \mathrm{~s}, p<0.001)$ showed itself to be more effective than the other doses $\left(20 \mathrm{mg} \cdot \mathrm{kg}^{-1}: \quad 356.2 \pm 66.00 \mathrm{~s}\right.$, and $40 \mathrm{mg} \cdot \mathrm{kg}^{-1}: 399.0 \pm$ $43.10 \mathrm{~s}, p<0.05)$, with reduced nociceptive responses, which were displayed as being equivalent to diclofenac $(223.3 \pm 59.56 \mathrm{~s}, \mathrm{p}<0.001)$ when compared to the control group ( $558.3 \pm 42.33 \mathrm{~s})$ (Fig. $2 \mathrm{~B})$. After these results, the study decided to work with the $80 \mathrm{mg} \cdot \mathrm{kg}^{-1}$ dose to perform the chronic inflammatory test.

\section{Treatment with $B$. trimera reduces paw edema after chronic inflammation}

As expected, the injection of FCA into the hind paws of the mice elicited marked local swelling and heat hypersensitivity. The evaluation of paw edema was conducted $48 \mathrm{~h}$ after the application of FCA (i.pl.) and also after the treatments. On the 2nd day after the FCA application, the water-treated animals presented an increase in paw edema $(0.75 \pm 0.13 \mathrm{~mm}$ to $0.85 \pm 0.12 \mathrm{~mm})$. However, the animals that were treated with $80 \mathrm{mg} \cdot \mathrm{kg}^{-1}$ of B. trimera $(0.31 \pm$ $0.03 \mathrm{~mm}, p<0.05)$ showed a significant reduction in paw edema when observed from the 5 th day, similar to the diclofenac-treated group $(0.36 \pm 0.01 \mathrm{~mm}, p<0.05)$. This

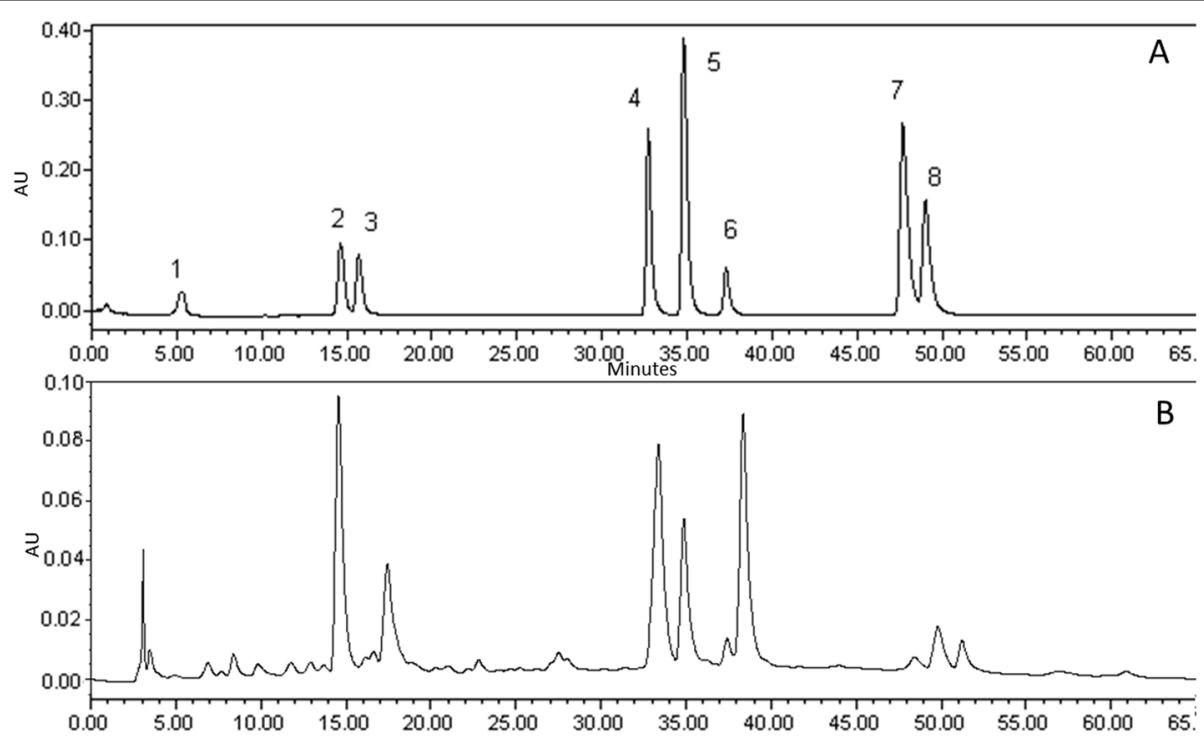

Fig. 1 HPLC chromatogram of the phenolic acids and flavonoids in the B. trimera aqueous extract at $254 \mathrm{~nm}$. The numbers in the chromatogram (A) correspond to the standards used (1: gallic acid; 2: chlorogenic acid; 3: caffeic acid; 4: rutin; 5: ellagic acid; 6: rosmarinic acid; 7: quercetin; and 8: luteolin) 


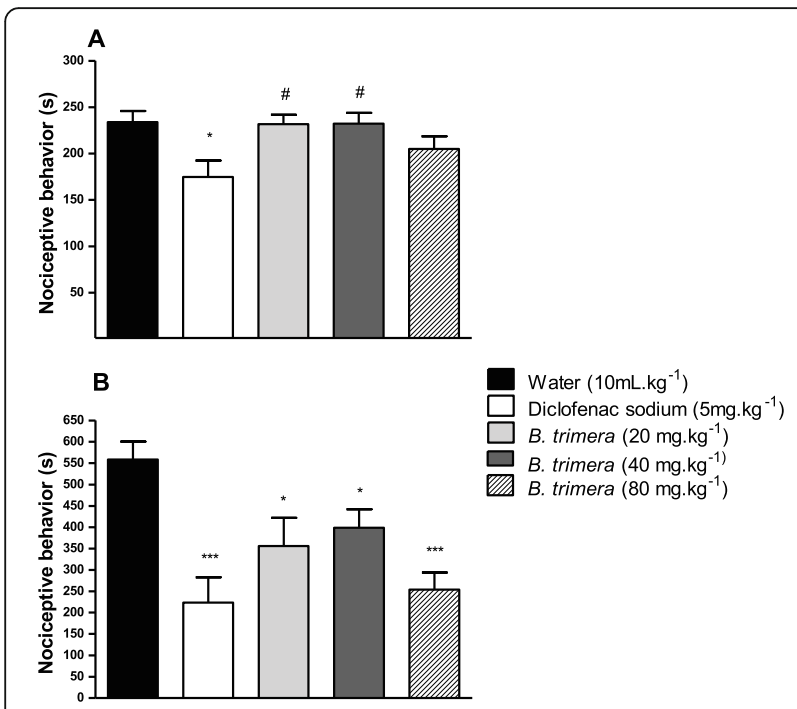

Fig. 2 Antinociceptive effects produced by the B. trimera aqueous extract after the formalin model. (A) The neurogenic phase and (B) the inflammatory phase $-1 \mathrm{~h}$ before the administration (i.pl.) into the right paw. Each bar represents the mean \pm standard error of 7-14 mice, depending on the group. ${ }^{*} p<0.05$ or ${ }^{* *} p<0.001$ represent the level of significance when compared to the water-treated animals; and ${ }^{\#} p<0.05$ when compared to diclofenac-treated animals (One-Way ANOVA, followed by the Student-Newman-Keuls (SNK) test)

result then confirmed the antiedematogenic action of the aqueous extract of B. trimera (Fig. 3).

Treatment with $B$. trimera decreases thermal hyperalgesia after chronic inflammation

After chronic inflammation was induced by FCA (i.pl.), the mice that were treated with the higher aqueous extract of B. trimera ( $80 \mathrm{mg} . \mathrm{kg}^{-1}$ p.o.) presented an increased hot plate latency $(18.67 \pm 1.32 \mathrm{~s}, p<0.001)$ when compared to the water-treated mice $(11.9 \pm 0.81 \mathrm{~s})$. In addition, the hot place latency levels after the treatment with the extract were similar to those that were observed after the diclofenac treatment $(16.67 \pm 1.26)$ (Fig. 4).

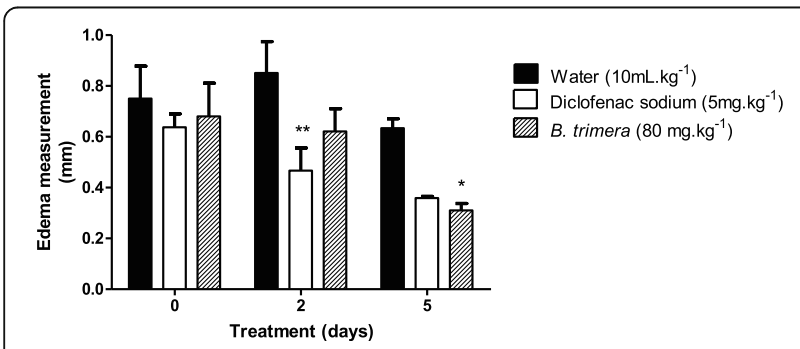

Fig. 3 Antiedematogenic effect of the $B$. trimera aqueous extract $(80 \mathrm{mg} / \mathrm{kg}$, p.o.) after the chronic inflammatory induction by FCA (i.pl.). Each bar represents the mean \pm standard error of 14-15 mice. ${ }^{*} p<0.05$ or ${ }^{* *} p<0.01$ represents the level of significance when compared to the water-treated group (Two-Way ANOVA, followed by the Bonferroni test)

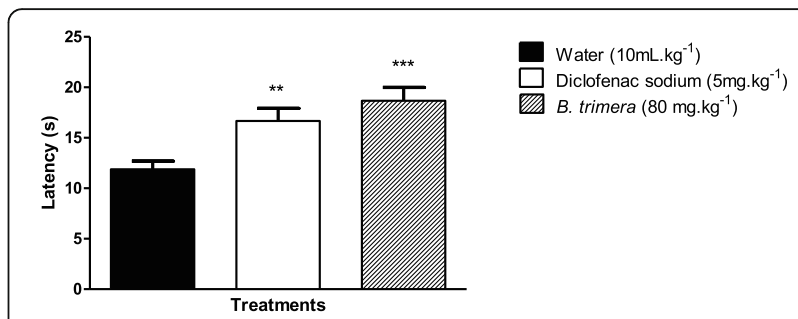

Fig. 4 Antinociceptive effects of the $B$. trimera aqueous extract in the thermal hyperalgesia test after the chronic inflammation was induced by FCA (i.pl.). Each bar represents the mean \pm standard error of 9 mice per group. ${ }^{* *} p<0.01$ or ${ }^{* * *} p<0.001$ represents the level of significance when compared to the water-treated animals (OneWay ANOVA, followed by the Student-Newman-Keuls (SNK) test)

Treatment with $B$. trimera decreases mechanical allodynia after chronic inflammation

$48 \mathrm{~h}$ after the FCA injection (i.pl), the study observed a significant increase in nociception sensitivity (water: $0.48 \pm 0.09 \mathrm{~g}$; diclofenac: $1.20 \pm 0.26 \mathrm{~g} ; \quad B$. trimera: $1.20 \pm 0.15 \mathrm{~g}$ ) when compared to the basal levels (water: $4.15 \pm 1.02 \mathrm{~g}$; diclofenac: $3.50 \pm 0.67 \mathrm{~g} ; B$. trimera: $3.35 \pm 0.38 \mathrm{~g}$ ). The daily administration of the B. trimera aqueous extract $\left(80 \mathrm{mg} \cdot \mathrm{kg}^{-1}\right.$ p.o.) over five days was able to reduce mechanical allodynia on the 5th day $(3.66 \pm 0.68 \mathrm{~g}, p<0.01)$, with similar levels as observed by the diclofenac treated group $(2.77 \pm 0.86$ g, $p<0.05)$ when compared to the control group $(0.60 \pm 0.13$ g) (Fig. 5).

\section{Myeloperoxidase measurement in the subcutaneous tissue of the mice after chronic inflammation}

In order to investigate the contribution of the neutrophils in the inflammatory response that was induced by FCA, the researchers performed the MPO assay, as described in Material and Methods. The results did not show any significant changes in the myeloperoxidase activity from the subcutaneous tissue of the mice, after the treatment with B. trimera $(1.84 \pm 0.28$ $\mathrm{DO} / \mathrm{g}$ tissue) or diclofenac $(1.34 \pm 0.23 \mathrm{DO} / \mathrm{g}$ tissue,

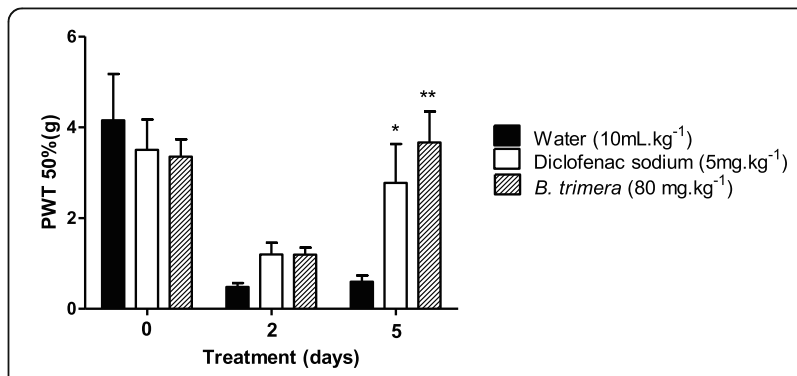

Fig. 5 Antinociceptive effects of an oral administration of the B. trimera aqueous extract on mechanical allodynia induced by FCA (i.pl.). Each bar represents the mean \pm standard error of $6-9$ mice. ${ }^{*} p<0.05$ or ${ }^{* *} p<0.01$ represents the level of significance when compared to the water-treated animals (Two-Way ANOVA, followed by the Bonferroni test) 
$p=0.25)$ when compared to the control group (1.90 \pm $1.44 \mathrm{DO} / \mathrm{g}$ tissue).

\section{Treatment with $B$. trimera decreases the number of white} blood cells (WBC)

It is well known that white blood cells are recruited during inflammatory processes [33]. Thus, the study decided to investigate if the $B$. trimera aqueous extract treatment was able to reduce the WBC count. The findings showed an equal reduction in the number of lymphocytes in the blood of the mice that were treated with $B$. trimera $\left(80 \mathrm{mg} \cdot \mathrm{kg}^{-1}\right.$ p.o.) and the mice that were treated with diclofenac sodium when compared to the control group (Table 1).

\section{Discussion}

The literature has reported B. trimera as a species of important anti-inflammatory properties [14]. However, most of these studies were performed using acute inflammatory models to state the anti-inflammatory effect of $B$. trimera [12-14]. In this context, to examine the role of the $B$. trimera aqueous extract on different models of chronic inflammation, the researchers treated the mice daily by gavage, with three different concentrations of the extract, in order to observe the nociceptive behavior. Moreover, the antioxidant activity of the extract was measured and the anti-inflammatory activity by two different assays was evaluated: the MPO assay and the white blood cells count. The investigation started with the HPLC analyses, which showed rosmarinic, ellagic, chlorogenic acid (phenolic acids), and rutin (flavonoids) as the main compounds detected in the aqueous extract of the aerial parts from $B$. trimera. These results are in accordance with previously reported works in the literature [20,34,35].

The antioxidant activity of the aqueous extract of the aerial parts from $B$. trimera has been described previously [17, 34, 35]. According to the classification of antioxidant activity, as reported by Fidrianny et al., (2015) [36], the aqueous extract of the aerial parts from $B$. trimera had a moderate antioxidant activity when detected by the DPPH assay. Previously, Rodriguez et al. (2009) [17] reported a similar value of inhibition of the B. trimera aqueous extract. Indeed, phenolic acids and flavonoids can donate electrons and stop chain reactions [37, 38]. The inhibitory effect of $B$. trimera on the reactive oxygen species (ROS) can be explained by two distinct mechanisms, which may or may not generate synergistic effects [39]. The same authors explained that the first mechanism involves the inhibition of the PKC protein expression and activity, and the second mechanism is associated with the downregulation of the $\mathrm{p} 47^{\text {phox }}$ phosphorylation of the nicotinamide adenine dinucleotide phosphate oxidase enzyme (NOX).

The present results also demonstrated an antiinflammatory effect of the $B$. trimera aqueous extract treatment $\left(80 \mathrm{mg} \cdot \mathrm{kg}^{-1}\right)$ during the inflammatory phase of the formalin test. On the contrary, none of the tested doses of the extract was effective against the nociceptive behavior during the neurogenic phase of the test. It is important to highlight that in the neurogenic phase of the formalin test, there was a release of the nociceptive mediators, leading to plasma leakage (edema), vasodilatation in the capillaries, and activation of the sympathetic fibers, mastocytes, and macrophages [40]. Yet, during the inflammatory phase, mediators, such as histamine, serotonin, bradykinin, and prostaglandins were released. Therefore, this phase is very sensitive to the drugs with peripheral actions [32]. In this scenario, the pretreatment with the lyophilized butanoic extract of $B$. trimera $(100 \mathrm{mg} / \mathrm{kg}$, i.p) markedly inhibited the carrageenan and dextran-induced inflammation and reduced the abdominal constrictions in the mice following the injection of acetic acid [13]. The same authors suggested that B. trimera showed anti-inflammatory and analgesic properties, which seemed to be due, at least partly, to the inhibition of prostaglandin biosynthesis via the cyclooxygenase blockade. As the aqueous extract of $B$. trimera was effective in decreasing the nociceptive behavior in the formalin test and as it showed an antiedematogenic action, the authors might suggest that it displays anti-inflammatory effects. According to de Oliveira et al. (2012), the phenolic enriched extract of B. trimera (15 mg. $\mathrm{kg}^{-1}$, i.p.) presented anti-inflammatory and antioxidant activities

Table 1 Leukocyte count (\%) in the blood of the different treated groups after the FCA injection (i.pl.) and the described treatments

\begin{tabular}{|c|c|c|c|}
\hline & Water (10 mL.kg $\left.{ }^{-1}\right)$ & Diclofenac Sodium (5 mg. $\mathrm{kg}^{-1}$ ) & B. trimera $\left(80 \mathrm{mg} \cdot \mathrm{kg}^{-1}\right)$ \\
\hline Lymphocytes & $83.00 \pm 3,21$ & $51.33 \pm 1.45^{* * *}$ & $64.66 \pm 1.76^{* \# \#}$ \\
\hline Neutrophils & $19.00 \pm 1.15$ & $9.00 \pm 1.15^{* * *}$ & $21.00 \pm 1.55^{\# \# \#}$ \\
\hline Eosinophils & $3.00 \pm 1.53$ & $9.33 \pm 0.66^{*}$ & $6.00 \pm 1.55$ \\
\hline Basophils & $1.33 \pm 0.33$ & $8.67 \pm 0.33^{* * *}$ & 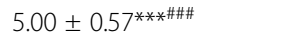 \\
\hline Monocytes & $3.66 \pm 1.33$ & $9.67 \pm 0.66^{*}$ & $4.50 \pm 1.50$ \\
\hline
\end{tabular}

${ }^{*} p<0.05$ and ${ }^{* * *} p<0.001$ when compared with water, and ${ }^{\# \#} p<0.01$ and ${ }^{\# \# \#} p<0.001$ when compared with diclofenac sodium (One-Way ANOVA, followed by the Student-Newman-Keuls (SNK) test) 
in the inflammatory pleurisy model due to the presence of the phenolic compounds [14].

In order to confirm the antinociceptive effect of the B. trimera aqueous extract in vivo, a chronic inflammatory model in the mice was achieved by using FCA (i.pl.). The daily treatment with the $B$. trimera aqueous extract $\left(80 \mathrm{mg} . \mathrm{kg}^{-1}\right.$, p.o.) reduced all of the nociceptive behaviors, as shown by the diclofenac sodium treatment levels $\left(5 \mathrm{mg} . \mathrm{kg}^{-1}\right.$, p.o.). The hot plate test caused a thermal stimulus that activated the nociceptors, transmitting nociceptive information to the dorsal horn of the spinal cord, and then to the cortical centers [41]. The Von Frey test was also stimulus-evoked to quantify the "pain-like" behavior or nociception [27], Thus, the response to the application of the Von Frey filaments to the skin, measured the tactile sensitivity, and was a surrogate marker of allodynia in the states of peripheral and/or central sensitization [42]. Therefore, all of the applied tests evaluated the antinociceptive effect of $B$. trimera in a pain model that caused central sensitization.

It is well known that FCA might provide a complex set of signals to the innate compartment of the immune system, resulting in altered leukocyte proliferation and differentiation [43]. In the present study, daily doses of the aqueous extract of $B$. trimera significantly decreased the count of the current peripheral lymphocytes, as well as increasing the basophils count; however, the neutrophils did not decrease. The positive control, diclofenac, also inhibited the accumulation of the leukocytes, as previously described by Prescott et al., (1989) [44]. The findings of this current study are in accordance with the MPO analyses, which did not present significant changes. Similar results were also observed as the enriched extract of $B$. trimera was shown to be effective in the inhibition of the volume of exudation, leukocyte migration, leukocyte differential cell count, and protein concentration [14]. Paul et al. (2009) [12] also showed that the aqueous extract of B. trimera in concentrations of 25,50 , and $100 \mathrm{mg} \cdot \mathrm{mL}^{-1}$ inhibited the T-lymphocytes proliferation in vitro. Thus, to understand how B. trimera decreases the lymphocyte levels, additional experiments need to be performed.

In summary, the present findings confirm the antiinflammatory effects of $B$. trimera. Although this aqueous extract is not much studied, it showed great outcomes in the inflammatory pain models that were used in this study. Besides, the current research also reinforces that these anti-inflammatory effects can be due to the saponins, flavonoids, and phenolic compounds, which were present in the aqueous extract.

\section{Conclusion}

Taken together, the data has reinforced the potential of the $B$. trimera aqueous extract as an anti-inflammatory and analgesic compound in a mice model of chronic inflammatory pain. Nevertheless, it is also necessary to develop more research focusing on the anti-inflammatory activity of this compound. More studies must be conducted in order to evaluate the safety, the administration route of the aqueous extract of $B$. trimera, and the lesser doses that need to be tested, to prove the efficacy as an antinociceptive treatment. However, as a large part of the Brazilian population uses medicinal plants, the current work using plant-based therapy could be seen to explain the clinical translational part of phytotherapy related to B. trimera.

\section{Abbreviations \\ DPPH: 2,2-Diphenyl-1-picrylhydrazyl; FCA: Freund's Complete Adjuvant; HPLC: High Performance Liquid Chromatography; LOD: Limit of Detection; LOQ: Limit of Quantification; MPO: Myeloperoxidase; OD: Optical Density; PWT: Withdrawal Threshold}

\section{Authors' contributions}

NSA and CP performed the nociceptive experiments. ABF and DSC contributed to the extract preparation and the phytochemical characterization. FTTA, LBV, and AHS contributed to the data interpretation and the manuscript preparation. AHS was the senior researcher responsible for designing this project. The author(s) read and approved the final manuscript.

\section{Funding}

This work was supported by the Lutheran University of Brazil (ULBRA).

\section{Availability of data and materials}

The datasets used and/or analyzed during the current study are available from the corresponding author upon reasonable request.

\section{Declarations}

Ethics approval and consent to participate

The Swiss male mice (35-40 g) were obtained from the Vivarium of the Lutheran University of Brazil (ULBRA). The animal care and experimental procedures were strictly conducted in accordance with the ARRIVE Guidelines (Kilkenny et al., 2011). All of the experiments were performed under the Consent and Surveillance of the Ethics Committee for Using Animals from ULBRA under Protocol n²013-20P.

Consent for publication

Not applicable.

\section{Competing interests}

The authors declare that they have no conflicts of interest related to this research.

\section{Author details}

${ }^{1}$ Graduate Program in Genetics and Toxicology (PPGGTA), Lutheran University of Brazil, Av. Farroupilha, n 8001, Bairro São José, Canoas, RS 92425-900, Brazil. ${ }^{2}$ Graduate Program in Cellular and Molecular Biology Applied to Health, Lutheran University of Brazil, Canoas, RS 92425-900, Brazil. ${ }^{3}$ Departamento de Farmacologia, ICB, Universidade Federal de Minas Gerais, Belo Horizonte, Brazil.

Received: 16 November 2020 Accepted: 13 September 2021

Published online: 26 October 2021

References

1. Kazemi S, Shirzad H, Rafieian-Kopaei M. Recent findings in molecular basis of inflammation and anti-inflammatory plants. Curr Pharm Des. 2018;24(14): 1551-62. https://doi.org/10.2174/1381612824666180403122003. 
2. Muley MM, Krustev E, McDougall JJ. Preclinical assessment of inflammatory pain. CNS Neurosci Ther. 2016;22(2):88-101. https://doi. org/10.1111/cns.12486.

3. Azab A, Nassar A, Azab AN. Anti-Inflammatory Activity of Natural Products. Molecules (Basel, Switzerland). 2016;21(10):1321.

4. Boller S, Soldi C, Marques MC, Santos EP, Cabrini DA, Pizzolatti MG, et al. Anti-inflammatory effect of crude extract and isolated compounds from Baccharis illinita DC in acute skin inflammation. J Ethnopharmacol. 2010; 130(2):262-6. https://doi.org/10.1016/j.jep.2010.05.001.

5. Brasileira F. 5th ed. Brasília, Brasil: Anvisa; 2010.

6. Budel JM, Duarte MR, Santos CAM, Farago PV, Matzenbacher NI. O progresso da pesquisa sobre o gênero Baccharis, Asteraceae: I - Estudos botânicos [The progress of research on the genus Baccharis, Asteraceae: I botanical studies]. Rev Bras Farmacogn. 2005;15(3):268-71. https://doi.org/1 0.1590/S0102-695X2005000300018.

7. Abad M, Bermejo P. Baccharis (compositae): a review update. Arkivoc. 2007; 2007(7):76-96. https://doi.org/10.3998/ark.5550190.0008.709.

8. Rabelo ACS, Costa DC. A review of biological and pharmacological activities of Baccharis trimera. Chem Biol Interact. 2018;296:65-75. https://doi.org/10.1 016/j.cbi.2018.09.002.

9. Barbosa RJ, Ratti da Silva G, Cola IM, Kuchler JC, Coelho N, Barboza LN, Menetrier JV, de Souza R, Zonta FN, Froehlich DL, Jacomassi E, Soares AA, Velasques LG, Veiga AA, Souza LM, Lovato E, Ribeiro-Paes JT, Gasparotto Junior A, Acco A, Lívero F. Promising therapeutic use of Baccharis trimera (Less.) DC. as a natural hepatoprotective agent against hepatic lesions that are caused by multiple risk factors. J Ethnopharmacol. 2020;254:112729.

10. Hussain T, Tan B, Yin Y, Blachier F, Tossou MC, Rahu N. Oxidative stress and inflammation: what polyphenols can do for us? Oxidative Med Cell Longev. 2016;7432797:1-9. https://doi.org/10.1155/2016/7432797.

11. de Oliveira CB, Comunello LN, Maciel ES, Giubel SR, Bruno AN, Chiela EC, Lenz G, Gnoatto SC, Buffon A, Gosmann G. The inhibitory effects of phenolic and terpenoid compounds from Baccharis trimera in Siha cells: differences in their activity and mechanism of action. Molecules (Basel, Switzerland). 2013;18(9):11022-32.

12. Paul EL, Lunardelli A, Caberlon E, de Oliveira CB, Santos RC, Biolchi V, et al. Anti-inflammatory and immunomodulatory effects of Baccharis trimera aqueous extract on induced pleurisy in rats and lymphoproliferation in vitro. Inflammation. 2009;32(6):419-25. https://doi.org/10.1007/s10753-009-9151-1.

13. Gené RM, Cartaña C, Adzet T, Marín E, Parella T, Cañigueral S. Antiinflammatory and analgesic activity of Baccharis trimera: identification of its active constituents. Planta Med. 1996;62(3):232-5. https://doi.org/10.1055/s-2 006-957866.

14. de Oliveira CB, Comunello LN, Lunardelli A, Amaral RH, Pires MG, da Silva $\mathrm{GL}$, et al. Phenolic enriched extract of Baccharis trimera presents antiinflammatory and antioxidant activities. Molecules. 2012;17(1):1113-23. https://doi.org/10.3390/molecules17011113.

15. Nogueira NP, Reis PA, Laranja GA, Pinto AC, Aiub CA, Felzenszwalb I, et al. In vitro and in vivo toxicological evaluation of extract and fractions from Baccharis trimera with anti-inflammatory activity. J Ethnopharmacol. 2011; 138(2):513-22. https://doi.org/10.1016/j.jep.2011.09.051.

16. Pádua B, Rossoni Júnior JV, Magalhães $C L$, Chaves MM, Silva ME, Pedrosa $M L$, et al. Protective effect of Baccharis trimera extract on acute hepatic injury in a model of inflammation induced by acetaminophen. Mediat Inflamm. 2014;196598:1-14. https://doi.org/10.1155/2014/196598.

17. Rodrigues $C R$, Dias JH, de Mello RN, Richter MF, Picada JN, Ferraz AB. Genotoxic and antigenotoxic properties of Baccharis trimera in mice. J Ethnopharmacol. 2009;125(1):97-101. https://doi.org/10.1016/j.jep.2009. 06.006 .

18. Harborne JB. Textbook of Phytochemical Methods. A Guide to Modern Techniques of Plant Analysis. 5th Edition, Chapman and Hall Ltd, London, 1998;21-72

19. Wagner H, Bladt S. Plant drug analysis: a thin layer chromatography atlas. 2nd ed. Berlin: Springer-Verlag; 1996. https://doi.org/10.1007/978-3-64200574-9.

20. Menezes AP, da Silva J, Fisher C, da Silva FR, Reyes JM, Picada JN, et al. Chemical and toxicological effects of medicinal Baccharis trimera extract from coal-burning area. Chemosphere. 2016;146:396-404. https://doi.org/1 0.1016/j.chemosphere.2015.12.028.

21. Singleton $V L$, Joseph AR. Colorimetry of total phenolics with phosphomolybdic-phosphotungstic acid reagents. Am J Enol Vitic. 1965;16: 144-58.
22. Woisky RG, Salatino A. Analysis of propolis: some parameters and procedures for chemical quality control. J Apic Res. 1998;37(2):99-105. https://doi.org/10.1080/00218839.1998.11100961.

23. Mensor LL, Menezes FS, Leitão GG, Reis AS, dos Santos TC, Coube CS, et al. Screening of Brazilian plant extracts for antioxidant activity by the use of DPPH free radical method. Phytother Res. 2001;15(2):127-30. https://doi. org/10.1002/ptr.687.

24. Kilkenny C, Browne W, Cuthill IC, Emerson M, Altman DG. National Centre for the replacement, refinement, and reduction of animals in research. Animal research: reporting in vivo experiments--the ARRIVE guidelines. J Cereb Blood Flow Metab. 2011;31(4):991-3. https://doi.org/10.1038/jcbfm.2 010.220 .

25. Hunskaar S, Hole K. The formalin test in mice: dissociation between inflammatory and non-inflammatory pain. Pain. 1987;30(1):103-14. https:// doi.org/10.1016/0304-3959(87)90088-1.

26. Larson AA, Brown DR, el-Atrash S, Walser MM. Pain threshold changes in adjuvant-induced inflammation: a possible model of chronic pain in the mouse. Pharmacol Biochem Behav 1986;24(1):49-53, DOl: https://doi.org/1 0.1016/0091-3057(86)90043-2.

27. Deuis JR, Dvorakova LS, Vetter I. Methods used to evaluate pain behaviors in rodents. Front Mol Neurosci. 2017;10:284. https://doi.org/10.3389/fnmol.2 017.00284.

28. Ankier SI. New hot plate tests to quantify antinociceptive and narcotic antagonist activities. Eur J Pharmacol. 1974;27(1):1-4. https://doi.org/10.101 6/0014-2999(74)90195-2.

29. Dixon WJ. Efficient analysis of experimental observations. Annu Rev Pharmacol Toxicol. 1980;20(1):441-62. https://doi.org/10.1146/annurev.pa.20. 040180.002301

30. Suzuki K, Ota H, Sasagawa S, Sakatani T, Fujikura T. Assay method for myeloperoxidase in human polymorphonuclear leukocytes. Anal Biochem. 1983;132(2):345-52. https://doi.org/10.1016/0003-2697(83)90019-2.

31. Bentley SA, Marshall PN, Trobaugh FE Jr. Standardization of the Romanowsky staining procedure: an overview. Anal Quantitative Cytol. 1980;2(1):15-8.

32. Tjølsen A, Berge OG, Hunskaar S, Rosland JH, Hole K. The formalin test: an evaluation of the method. Pain. 1992;51(1):5-17. https://doi.org/10.1016/03 04-3959(92)90003-T.

33. Muller WA. Getting leukocytes to the site of inflammation. Vet Pathol. 2013; 50(1):7-22. https://doi.org/10.1177/0300985812469883.

34. do Nascimento DSM, Oliveira RM, Camara R, Gomes DL, Monte J, Costa M, Fernandes J M, Langassner S, Rocha H. baccharis trimera (Less.) DC Exhibits an Anti-Adipogenic Effect by Inhibiting the Expression of Proteins Involved in Adipocyte Differentiation. Molecules (Basel, Switzerland). 2017;22(6):972.

35. Sabir SM, Athayde ML, Boligon AA, Rocha JBT. Antioxidant activities and phenolic profile of Baccharis trimera, a commonly used medicinal plant from Brazil. S Afr J Bot. 2017;113:318-23. https://doi.org/10.1016/j.sajb.2017. 09.010 .

36. Fidrianny I, Aristya T, Hartati R. Antioxidant capacities of various leaves extracts from three species of legumes and correlation with total flavonoid, phenolic, carotenoid content. Int J Pharm Phytopharmacol Res. 2015;7(3): 628-34.

37. Kaurinovic B, Vastag D. Flavonoids and phenolic acids as potential natural antioxidants, antioxidants, Emad Shalaby. IntechOpen. 2019. https://doi. org/10.5772/intechopen.83731.

38. Singh DP, Verma S, Prabha R. Investigations on antioxidant potential of phenolic acids and flavonoids: the common phytochemical ingredients in plants. J Plant Biochem Physiol. 2018;6(03):3. https://doi.org/10.4172/23299029.1000219.

39. de Araújo GR, Rabelo AC, Meira JS, Rossoni-Júnior JV, Castro-Borges W, Guerra-Sá R, et al. Baccharis trimera inhibits reactive oxygen species production through PKC and down-regulation p47 ${ }^{\text {phox }}$ phosphorylation of NADPH oxidase in SK Hep-1 cells. Exp Biology Med. 2017;242(3):333-43. https://doi.org/10.1177/1535370216672749.

40. Capone F, Aloisi AM. Refinement of pain evaluation techniques. The formalin test. Ann Ist Super Sanita. 2004;40(2):223-9.

41. Bannon AW, Malmberg AB. Models of nociception: hot-plate, tail-flick, and formalin tests in rodents. Curr Protoc Neurosci. Chapter 8. 2007. https://doi. org/10.1002/0471142301.ns0809s41.

42. Christensen SL, Hansen RB, Storm MA, Olesen J, Hansen TF, Ossipov M, et al. Von Frey testing revisited: provision of an online algorithm for improved 
accuracy of 50\% thresholds. Eur J Pain. 2020;24(4):783-90. https://doi.org/1 0.1002/ejp.1528.

43. Billiau A, Matthys P. Modes of action of Freund's adjuvants in experimental models of autoimmune diseases. J Leukoc Biol. 2001;70(6):849-60.

44. Prescott MF, McBride CK, Venturini CM, Gerhardt SC. Leukocyte stimulation of intimal lesion formation is inhibited by treatment with diclofenac sodium and dexamethasone. J Cardiovasc Pharmacol. 1989;14(6):S76-81. https://doi. org/10.1097/00005344-198906146-00016.

\section{Publisher's Note}

Springer Nature remains neutral with regard to jurisdictional claims in published maps and institutional affiliations.

\section{Submit your manuscript to a SpringerOpen ${ }^{\circ}$ journal and benefit from:}

- Convenient online submission

- Rigorous peer review

- Open access: articles freely available online

High visibility within the field

- Retaining the copyright to your article

Submit your next manuscript at $\boldsymbol{\nabla}$ springeropen.com 